\title{
Ecology of Sipuncula
}

\author{
G.-V. V. Murina \\ Institute of Biology of the Southern Seas, Academy of Sciences Uk. SSR, 2 Nahimov St., Sevastopol, USSR
}

\begin{abstract}
The marine Sipuncula are regarded as consisting of 1 class, 4 families, 13 genera and 367 species and subspecies. Sipuncula are widespread in the benthos of the World Ocean: from $82^{\circ} \mathrm{N}$ and $77^{\circ} \mathrm{S}$ to the equator, and from the littoral to a depth of $7000 \mathrm{~m} ; 63 \%$ of the species are confined to the shelf. Temperatures tolerated range from -1.9 to $29^{\circ} \mathrm{C}$; however, most species are found within the $20^{\circ} \mathrm{C}$ isotherm. The geographical distribution is confined to seas with normal oceanic salinity. The range for survival and reproduction is 27 to $44 \% \mathrm{~S}$. Sipuncula are mainly deposit feeders. According to the mode of feeding and motility, the Sipuncula comprise 4 ecological groups: (1) burrowers, indiscriminately swallowing the substratum; (2) worms hiding in vacant shelters and collecting detritus; (3) waiting sestonophages; (4) sessile worms, scraping off food from the substratum
\end{abstract}

\section{INTRODUCTION}

Sipunculans * may be classified as unsegmented, vermiform, bilaterally symmetrical coelomate Protostomia, which in the course of evolution have rather prominently differentiated from the main line of Protostomia, leading to the Annelida and Mollusca.

At present, 367 species and subspecies of Sipuncula are known, forming 13 genera, 4 families, and 1 class.

High densities in certain biotopes, averaging 8000 individuals $\mathrm{m}^{-2}$ (Chapman, 1955), the muscular body devoid of calciferous formations, and the lack of protective shell or tube render the sipunculans an easily available prey for other animals. Sipunculans have been reported from the alimentary tracts of actinians, molluscs, crabs and seastars. They are the sole food source for the gastropod Mitra litterata, a common inhabitant of the Hawaiian waters, and constitute a rather important part of the ration of benthophage fishes. They were found in the stomachs of over 50 fish species, belonging to 2 orders of elasmobranch and 17 families in 6 orders of teleosts, including such important food-fish as cod, plaice and haddock (Kohn, 1975).

Sipunculans were considered edible some 200 yr ago: Pallas (1774) named one of the first scientifically described sipunculan worms Lumbricus edulis (=Siphonosoma edule). Native populations of

\footnotetext{
- If the phylum is to be called Sipuncula it seems reasonable and logical to use the term 'sipunculan' instead of 'sipunculoid' or 'sipunculid' (Stephan and Edmonds, 1972)
}

Malaya, Caroline Islands and South China consume large specimens of the genera Sipunculus, Siphonosoma and Phascolosoma, reaching $60 \mathrm{~cm}$ in length and 2 to $2.5 \mathrm{~cm}$ in diameter (Sato, 1935; Chin, 1947). According to recent American studies (Rice and McIntyre, 1972; Rice, 1976) these soft-bodied creatures are able to bore into hard rock, thus playing an important role in the destruction of limestone and coral reefs.

The present study has 2 aims: (1) to analyse the depth distribution of sipunculans in the benthos of the World Ocean; (2) to generalise data on the ecology of sipunculans, to reveal their reaction to the principal abiotic factors and to arrange them into major ecological groups.

\section{MATERIAL}

In 1979 the author completed a long-term study on all collections of sipunculans available in the research institutions of this country, consisting of over 12000 specimens from 2000 stations. A large part of the material (5860 specimens from 725 stations) was collected by the workers of the P. I. Shirshov Institute of Oceanology, Academy of Sciences of USSR, during expeditions on R/S 'Vityaz', 'Dmitry Mendeleev', 'Akademik Kurchatov' and 'Ob'. Another collection, resulting from $100 \mathrm{yr}$ of work, was kindly placed at the author's disposal by the Zoological Institute, USSR Academy of Sciences (3700 specimens from 575 stations). Use was also made of the material from other research and educational establishments of the USSR, 
as well as of the collections of the author's foreign colleagues from the USA (Edward Cutler), Romania (Michai Bàcescu), and Yugoslavia (Dushan Zavodnik).

The author's personal collection was formed as a result of expeditions on the research ship 'Akademik A. Kovalevsky' in the Red Sea and Aden Bay (1963), to Cuba (1964-1965), in the Mediterranean Sea (1974, $1978,1979)$ and on the research ship 'Dmitry Mendeleev' in the south-western part of the Pacific Ocean.

The author defined 129 species and subspecies of Sipuncula, which is $36 \%$ of all the known representatives of this group in the World Ocean. They belong to 11 genera and 4 families. Two subgenera and over 40 species and subspecies had previously been unknown. In the research institutions of the USSR there exists exhaustive information on the genera Cloeosiphon, Phascolopsis, Onchnesoma and fairly large collections of the genera Golfingia, Phascolion, Sipunculus, Aspidosiphon, Lithacrosiphon, Phascolosoma, and Siphonosoma.

After processing the data from the above-mentioned collections, compiling lists of material from the major Soviet and foreign expeditions on a station basis and analysing practically all publications available on the subject, the author obtained information on the ecology and depth distribution of all species and subspecies of the phylum Sipuncula. All this resulted in a new classification of this group, which is significantly different from the previously adopted classification (Stephen and Edmonds, 1972 'The Phyla Sipuncula

Table 1. Taxa of the phylum Sipuncula

\begin{tabular}{|c|c|c|c|}
\hline \multirow{2}{*}{\multicolumn{2}{|c|}{ Family, genus, subgenus }} & \multicolumn{2}{|c|}{ Number of } \\
\hline & & species & subspecies \\
\hline \multirow{2}{*}{\multicolumn{2}{|c|}{$\begin{array}{l}\text { Phylum SIPUNCULA Sedgwick, } 1898 \\
\text { Class Sipunculida Hatschek, } 1883\end{array}$}} & 336 & 52 \\
\hline & Hatschek, 1883 & 336 & 52 \\
\hline \multicolumn{2}{|c|}{ Family Aspidosiphonidae Quatrefages, 1865} & 58 & 10 \\
\hline I Gen. & Aspidosiphon Diesing, 1851 & 53 & 10 \\
\hline \multirow[t]{2}{*}{ Subgen. } & 1 Aspidosiphon (s. str.) Diesing, 1851 & 28 & 4 \\
\hline & 2 Paraspidosiphon Stephen, 1965 & 26 & 6 \\
\hline II Gen. & Cloeosiphon Grube, 1868 & 1 & - \\
\hline III Gen. & Lithacrosiphon Shipley, 1902 & 3 & - \\
\hline \multicolumn{2}{|c|}{ Family Golfingiidae Stephen et Edmonds, 1972} & 168 & 21 \\
\hline I Gen. & Golfingia Lankester, 1885 & 97 & 19 \\
\hline \multirow[t]{7}{*}{ Subgen. } & 1 Golfingia (s. str.) Fisher, 1950 & 25 & 9 \\
\hline & 2 Apionsoma Sluiter, 1902 & 10 & - \\
\hline & 3 Dushana Murina, 1975 & 2 & - \\
\hline & 4 Golfingiella Stephen, 1965 & 4 & - \\
\hline & 5 Nephasoma Pergament, 1946 & 39 & 10 \\
\hline & 6 Siphonoides Murina, 1967 & 2 & - \\
\hline & 7 Thysanocardia Fisher, 1950 & 15 & - \\
\hline II Gen. & Onchnesoma Koren et Danielsen, 1875 & 4 & - \\
\hline III Gen. & Phascolion Théel, 1875 & 41 & 2 \\
\hline IV Gen. & Phascolopsis Fisher, 1950 & 1 & - \\
\hline V Gen. & Themiste Gray, 1826 & 25 & - \\
\hline \multicolumn{2}{|c|}{ Family Phascolosomatidae Stephen et Edmonds, 1972} & 65 & 5 \\
\hline I Gen & Phascolosoma Leuckart, 1826 & 65 & 5 \\
\hline \multirow[t]{4}{*}{ Subgen. } & 1 Phascolosoma (s. str.) Leuckart, 1828 & 42 & 5 \\
\hline & 2 Antillesoma Stephen et Edmonds, 1972 & 7 & - \\
\hline & 3 Rueppellisoma Stephen et Edmonds, 1972 & 8 & - \\
\hline & 4 Satonus Stephen et Edmonds, 1972 & 8 & - \\
\hline \multicolumn{2}{|c|}{ Family Sipunculidae Quatrefages, 1865} & 45 & 16 \\
\hline I Gen. & Siphonomecus Fisher, 1947 & 1 & - \\
\hline II Gen. & Siohonosoma Spengel, 1912 & 22 & 9 \\
\hline \multirow[t]{3}{*}{ Subgen. } & 1 Siphonosoma (s. str.) Fisher, 1950 & 16 & - \\
\hline & 2 Damosiphon Fisher, 1950 & 3 & 6 \\
\hline & 3 Hesperosiphon Fisher, 1950 & 3 & 3 \\
\hline III Gen. & Sipunculus Linnaeus, 1776 & 19 & 7 \\
\hline IV Gen. & Xenosiphon Fisher, 1947 & 3 & - \\
\hline \multirow[t]{3}{*}{ Subgen. } & 1 Xenosiphon (s. str.) Fisher, 1954 & 1 & - \\
\hline & 2 Austrosiphon Fisher, 1954 & 1 & - \\
\hline & 3 Xenosiphon Johnson, 1969 & 1 & - \\
\hline
\end{tabular}


and Echiura') with regard to the rank and place of several major taxa in the system (Table 1). For example, Aspidosiphon s. str. and Paraspidosiphon are considered to be subgenera of the genus Aspidosiphon; the genus Phascolopsis is referred to the family Golfingiidae and not to the family Sipunculidae; the subgenera Phascolana, Fisherana and Mitosiphon are regarded as synonyms of the subgenus Apionsoma. Thus, in the present report the phylum Sipuncula is discussed as consisting of 1 class, 4 families, 13 genera, 336 species ( 315 monotypic and 21 polytypic) and 31 subspecies (excepting nominatives). This is 45 species and subspecies more than has been included in the above-mentioned earlier classification.

\section{RESULTS AND DISCUSSION}

On the basis of data on habitat depths involving all 367 taxa of the phylum, their bathymetric distribution was analysed. The method proposed by N. G. Vinogradova (1969) was applied to find regularities in their depth distribution, if any. The method consists of constructing 3 curves depicting the number of taxa in each $100 \mathrm{~m}$ layer, which exhibit their upper (appearance) and lower (disappearance) distribution limits in this layer. The curves (Fig. 1 to 3 ) do not include species found only once.

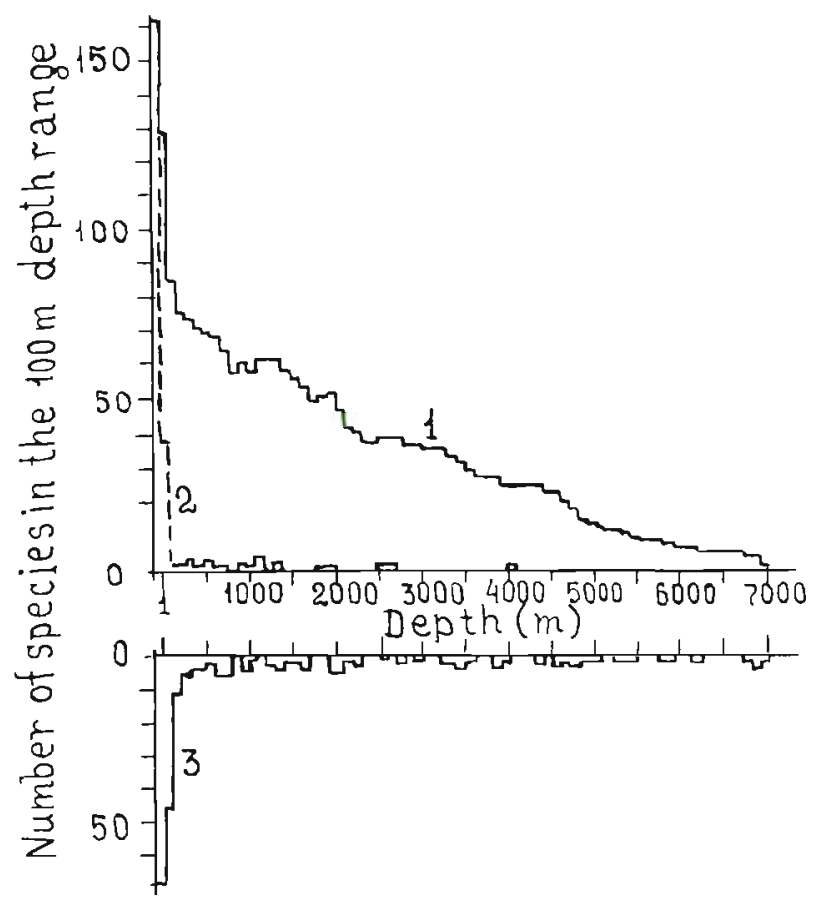

Fig. 1. Number of Sipuncula species as a function of increasing habitat depth (isolated rare species omitted). 1: total number of species; 2 : species appearing in the depth interval; 3: species disappearing from the depth interval
Fig. 1 shows that there is a sharp decline in the number of species on the interphase of the littoral zone and the sublittoral zone. All the peaks of the curve showing the number of species at this depth fall in the range of 300 to $1600 \mathrm{~m}$. At this depth the disappearance of certain species may also be observed, i.e. there is a small change in species composition. Below $1600 \mathrm{~m}$ only a few forms exist and these disappear totally below $4000 \mathrm{~m}$.

The above analysis of the bathymetric distribution of Sipuncula in the World Ocean and its comparison with the currently used system of faunistic depth zonation of the benthic marine fauna (Belyaev et al., 1959) produced the following change in the fauna on the interphase between the littoral and sublittoral zones: (1) almost half the number of species is confined to the upper euphotic zone of the shelf; (2) there is a lack of an independent fauna in the transition area from the sublittoral to the bathyal zone; (3) the composition of the bathyal and, especially abyssal, fauna is poor; (4) there is a significant number of eurybathic species with a broad depth range.

Four larger taxa (families) have 2 differing types of depth distributions. The first type, characteristic of the family Golfingiidae, features a significant increase in the number of sublittoral species as compared with the littoral forms and a gradual reduction in the number of species downwards (Fig. 2). The percentage of species

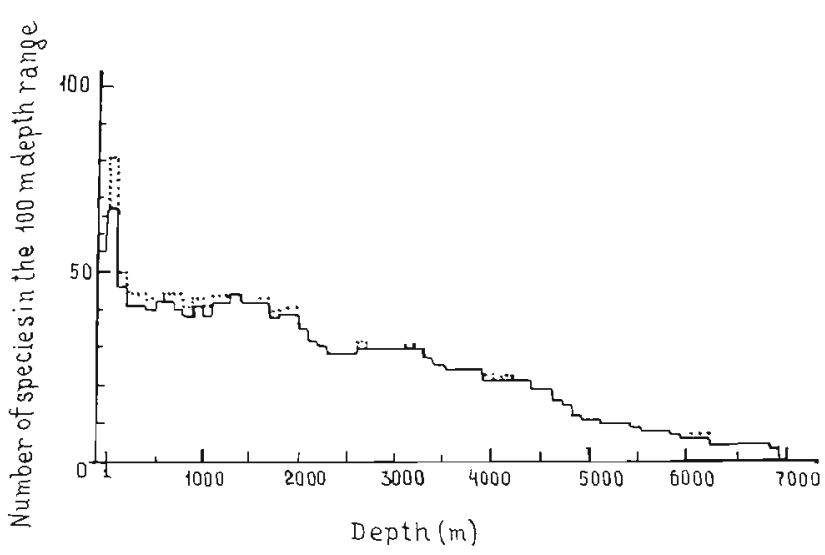

Fig. 2. Number of Golfingiidae species as a function of increasing habitat depth. Dotted line: total number of species; continuous line: isolated rare species omitted

belonging to the 2 shallow-water groups of the littoral and sublittoral zones is $46 \%$. The second type is characteristic of the thermophilic Aspidosiphonidae, Phascolosomatidae and Sipunculidae and comprises species rather strictly confined to the shelf, dropping sharply in their number in the bathyal and abyssal zones (Fig. 3). The share of shelf forms in each of the taxa is 83,81 , or $75 \%$ 


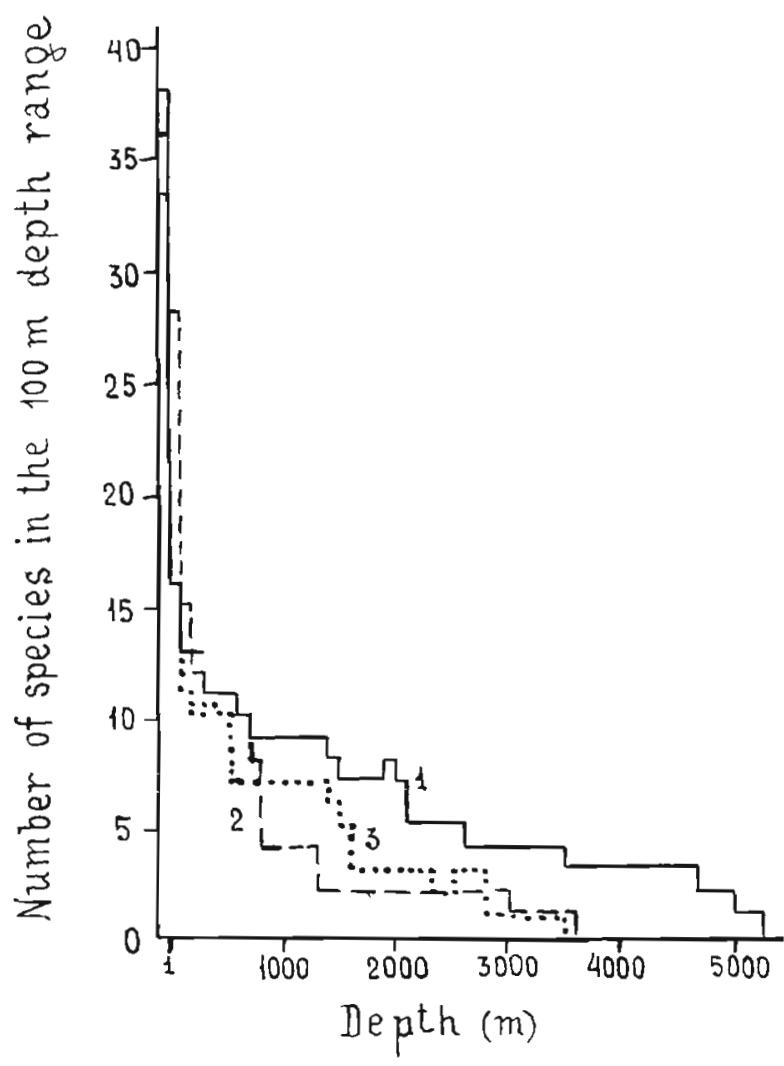

Fig. 3. Number of species from the 3 Sipuncula families as a function of increasing habitat depth (isolated rare species omitted). 1: Phascolosomatidae; 2: Aspidosiphonidae; 3: Sipunculidae

The most favourable biotopes for the sipunculans of the shelf, to which over one half of the lower taxa of the phylum belong, are fine sand, silty sand and sandy silt, coral and limestone reefs, rocks with fissures, sandy beaches, sea-grass groves, algae thickets, mangrove swamps, and clusters of mussels.

According to their mobility, habitat and mode of feeding (using analyses of gut contents and literature sources), the sipunculans can be divided into 4 principal ecological groups or life forms: (1) burrowing, actively moving worms indiscriminately swallowing the substratum (infauna); (2) semimobile worms hiding in empty shells and tubes, and collecting sediments with tentacles (mostly epifauna); (3) free-living, semimobile, waiting sestonophages (epifauna and cryptofauna); (4) sessile, endolithic forms scraping off detritus from the substratum with papillae and hooks of the introvert (cryptofauna)

Thus, about $80 \%$ of species of this phylum were identified as belonging to one of these groups. Among them, the largest group comprises burrowing-swallowing worms; the second largest, sessile worms scraping off detritus from the substratum; the third, hidingcollecting worms; and the fourth, waiting sestonophages.
Burrowing worms were rather more active in the soft, silty or sandy grounds, utilizing them both for protection and as a food source. The worms ingested indiscriminately, swallowing the sediments through their pharynx. Tentacles and hooks of the introvert are not necessary for this purpose (which may explain their poor development). Worms feeding on fine sand, silty sand or sandy silt (deposit-feeders) are characterized by a high index of intestinal filling*.

Burrowing and swallowing forms are represented by species belonging to 9 genera of 3 families: the genera Phascolopsis, Onchnesoma (complete), Golfingia (almost complete) of the family Golfingiidae, 4 genera of the families Sipunculidae (complete) and Phascolosomatidae (several, mostly deep-sea forms).

The second ecological group is more uniform than its taxonomy may suggest. About one fourth of the lower taxa of Aspidosiphon, most Phascolion forms and certain Golfingia species belong to this group. These smaller worms use as shelter (refuge) empty mollusc shells and tubes of polychaetes, as well as tests of Foraminifera and tubes of Pogonophora. The only exception is the deep-sea Phascolion lutense which builds thick, gray tubes of silt; it feeds by well developed tentacles on its introvert, collecting detritus from the surrounding sediment surface (deposit feeder).

Having grown, the worms change their narrow homes for larger shelters. Sipunculans prefer to find shelter in easily irrigated shells of gastropods and scaphopods bored by predatory molluscs of the family Naticidae. After occupying the shell the worm exudes a sticky substance, glueing the entrance of the shell with cemented mud, sand or silt, thus making a hard cover with a little opening in the center for the introvert. The worms usually move very little.

The density of this ecological group tends to be limited by the number of available empty shells and tubes (Hylleberg, 1975). Most frequently, the worms are found in the sublittoral zone, where they favour coarse grained sands. However, there are several species (Golfingia improvisa, G. minuta, G. schuettei, Phacolion pacificum), which abound in the soft silty soils of the deep seas (bathyal and abyssal zones).

Species of the genus Themiste and the subgenus Thysanocardia (genus Golfingia), characterized by a well developed dichotomous crown of tentacles, differ from the above-mentioned species in their mode of feeding. They are waiting sestonophages or suspension feeders. They feed by a ciliary mucous mechanism. Particles of detritus suspended in the water settle on the mucous-covered ciliary crown, where the move

\footnotetext{
- Ratio of food weight in the intestine to the weight of the animal, multiplied by 10000
} 
ment of cilia gathers them into lumps of food and directs them into the mouth opening. These are mostly sublittoral worms, inhabiting seas of the tropical and temperate zones.

The fourth ecological group consists of semi-mobile worms which shelter from their antagonists in cracks and cavities in the hard substratum. They should be able, to a certain extent, to bore hard rock - such as limestone, polypstone, lithothamnium - as this seems the only way to enlarge their homes. Boring is a complex mechanical and chemical process; important are special cuticular structures (posterior shield, papillae of body), containing collagen, and secretory products of epidermal glands (Rice and McIntyre, 1972; Williams and Margolis, 1974; Rice, 1976; Vouss-Foucart et al., 1978). Members of this group scrape off the substratum particles of detritus employing numerous rows of hooks, or prominent conical papillae of the introvert (deposit feeders). Evidently, the littoral species Lithacrosiphon cristatus is characterized by a high index of intestinal filling (Table 2).

The principal biotope of the burrowing sipunculans is dead coral reef. The endolithic worms are represented mostly by the species of the 2 families Phascolosomatidae and Aspidosiphonidae, and the genera Phascolosoma, Aspidosiphon, Lithacrosiphon, and Cloeosiphon.
The proposed classification of sipunculans according to their motility (determined by the character of substratum and mode of feeding) naturally does not account for all the variety of ecological forms of Sipuncula as certain species feature a mixed mode of feeding and are capable of inhabiting different biotopes. Specific habitats are populated by species inhabiting the roots of marine angiosperms, vast fields of brown and red algae, and accumulations of bivalve molluscs; others live as commensals of live solitary corals, scleractinian corals, or sponges, or inhabit mangrove swamps leading a semi-terrestrial life.

Preferences of sipunculans as to the quality of substrates are correlated with their bathymetric distribution (Table 3 ). In this case, depth is the factor determining the composition of deposits and conditions of sedimentation. Computations show that Golfingia e. eremita and G. m. margaritacea prefer coarse sediments: sand, sand and gravel, silty sand. The firstnamed species was not found in fine silt. $G$. v. vulgaris and Phascolion strombi mostly abound on the finealeurithic silt; such correlation is more pronounced for G. v. vulgaris than for Phascolion strombi.

The common species of the continental slope (bathyal zone), Golfingia murinae and Onchnesoma steenstrupii, were found predominantly on silty sand and fine-aleurithic silt.

Table 2. Indices of intestinal filling in certain species of Sipuncula. In brackets: number of empty intestines

\begin{tabular}{|c|c|c|c|c|}
\hline & Taxa & Location & $\begin{array}{l}\text { Index in prodecimille } \\
\text { min-max }\end{array}$ & $\begin{array}{l}\text { Number of } \\
\text { specimens }\end{array}$ \\
\hline & \multicolumn{4}{|l|}{ Family Aspidosiphon } \\
\hline 1 & Aspidosiphon kovalevskii & Adriatic Sea, silty sand & $541-894$ & \\
\hline 2 & A. s. steenstrupii & Cuba, coral reef & $188-395$ & $4(1)$ \\
\hline \multirow[t]{2}{*}{3} & Cloeosiphon aspergillus & Ryukyu, coral reef & 619 & $2(0)$ \\
\hline & Cloeosiphon aspergillus & New Hebrides, coral reef & 490 & $2(1)$ \\
\hline \multirow[t]{3}{*}{4} & Lithacrosiphon cristatus & Cuba, coral reef & $2199-2556$ & $2(1)$ \\
\hline & Lithacrosiphon cristatus & Indian Ocean, coral reef & $114-5813$ & $3(0)$ \\
\hline & \multicolumn{4}{|l|}{ Family Phascolosomatidae } \\
\hline 5 & Phascolosoma asser & Sumatra, coral reef & $337-1620$ & \\
\hline 6 & P. esculentum & South China Sea, mangrove beach & $2198-1373$ & $2(0)$ \\
\hline 7 & P. granulatum & West Africa, polyp-stone & $257-902$ & $3(0)$ \\
\hline 8 & P. japonicum & Bering Sea, rocky littoral & $239-1703$ & $4(1)$ \\
\hline 9 & P. lacteum & Ryukyu, coral reef & $260-648$ & $10(1)$ \\
\hline 10 & P. nigrescens & Cuba, coral reef & $331-521$ & $2(0)$ \\
\hline 11 & P. onomichianum & Cuba, coral reef & $1100-2100$ & $3(1)$ \\
\hline 12 & $P$ perculens & South China Sea, rocky littoral & $262-1558$ & $3(0)$ \\
\hline 13 & P. S. scolops & Red sea, coral sand & $226-1071$ & $3(0)$ \\
\hline \multirow[t]{3}{*}{14} & P. thomense & Cuba, coral reef & $51-297$ & $3(1)$ \\
\hline & & & & $3(0)$ \\
\hline & \multicolumn{4}{|l|}{ Family Sipunculidae } \\
\hline 15 & Sipunculus n. nudus & Hainan, sandy beach & $2559-6162$ & \\
\hline \multirow[t]{2}{*}{16} & Siphonosoma australe & Hainan, mangrove beach & $945-1643$ & $3(0)$ \\
\hline & \multicolumn{4}{|l|}{ Family Golfingiidae } \\
\hline \multirow[t]{2}{*}{17} & Themiste blanda & Posiette Bay, biocenosis of & 322 & \\
\hline & & Modiolus difficilus & & $5(4)$ \\
\hline
\end{tabular}


Table 3. Density of certain common species of Sipuncula at different depths of benthic areas of the World Ocean*

\begin{tabular}{|c|c|c|c|c|c|c|c|c|c|c|c|}
\hline Species & $\begin{array}{c}\text { Number of } \\
\text { benthic } \\
\text { stations." }\end{array}$ & $\begin{array}{c}0- \\
100\end{array}$ & $\begin{array}{l}101- \\
200\end{array}$ & $\begin{array}{l}201- \\
300\end{array}$ & $\begin{array}{l}301- \\
500\end{array}$ & $\begin{array}{l}\text { Deptr } \\
501- \\
1000\end{array}$ & $\begin{array}{l}h(\mathrm{~m}) \\
1001- \\
2000\end{array}$ & $\begin{array}{l}2001- \\
3000\end{array}$ & $\begin{array}{l}3001- \\
4000\end{array}$ & $\begin{array}{l}4001- \\
5000\end{array}$ & $\begin{array}{l}5001- \\
6000\end{array}$ \\
\hline Golfingia improvisa & 69 & - & $19 \pm 4$ & $8 \pm 4$ & - & $0.8 \pm 0.2$ & $0.3 \pm 2$ & $0.7 \pm 0.2$ & $0.4 \pm 0.1$ & $0.7 \pm 0.2$ & $0.1 \pm 0.04$ \\
\hline G. m. margaritacea & 205 & $8.2 \pm 0.7$ & $8.6 \pm 0.7$ & $9 \pm 2$ & $7 \pm 1$ & $6.5 \pm 1.5$ & $6 \pm 2$ & $5 \pm 2$ & - & - & - \\
\hline G. minuta & 77 & $22 \pm 4$ & $10 \pm 1$ & $17 \pm 3$ & $10 \pm 3$ & $10 \pm 3$ & $0.5 \pm 0.2$ & $0.6 \pm 0.2$ & $0.5 \pm 0.2$ & $0.7 \pm 0.2$ & $1 \pm 0.2$ \\
\hline G.murina & 72 & - & $5 \pm 2$ & $24 \pm 10$ & $10 \pm 2$ & $15 \pm 2$ & $13 \pm 2$ & $9 \pm 2$ & $8 \pm 2$ & $7 \pm 3$ & - \\
\hline G.v. vulgaris & 142 & $10 \pm 1$ & $8 \pm 1$ & $9 \pm 2$ & $13 \pm 2$ & $5 \pm 1$ & $5 \pm 2$ & $5 \pm 2$ & $4 \pm 2$ & $4 \pm 2$ & $6 \pm 2$ \\
\hline Onchnesoma steenstrupii & 49 & $30 \pm 3$ & $12 \pm 3$ & $22 \pm 16$ & $12 \pm 4$ & $18 \pm 1$ & $14 \pm 5$ & $4 \pm 4$ & $4 \pm 4$ & - & - \\
\hline
\end{tabular}

In the abyssal zone, sipunculans usually inhabit eutrophic areas distinguished by Sokolova (1976). Only a few Golfingia species were observed on the margins of the oligotrophic regions, or where these regions turn into shelves of islands or underwater mountains. These worms are probably capable of existing on the sparse organic matter available on the upper layer of sediments not yet buried.

More than half of the mass species of Sipuncula live in the shallow-water zones of tropical and subtropical seas (Murina, 1977). On the shelf (average annual temperature $20^{\circ} \mathrm{C}$ ) were found species of 3 mostly thermophilic/coralphilic families: Phascolosomatidae, Aspidosiphonidae and Sipunculidae. The widespread eurybathic Golfingiidae occurred over the widest temperature range $\left(-1.9\right.$ to $29^{\circ} \mathrm{C}$ ) (Cutler, 1973; Murina, 1977). The minimal temperature of abyssal habitats is not very different from the winter temperature of habitats in the shallow-water zone in the northern part of their distributional area. Only a few species of Sipuncula, mostly Golfingiidae, have adapted to the lowest temperature of the shelf in the high latitudes, while the lower temperature of the abyssal and ultraabyssal zone was acceptable to a far larger number of species in all families.

Low salinity significantly limits the geographical distribution of the worms. This fact explains their absence from low-salinity seas, such as the sea of Azov, the Caspian Sea, and the Baltic Sea. The number of Sipuncula species is very low in the White Sea and the Siberian Sea (3 to 4 species), which are known for their low salinity (24 to $27 \%$ S). Sipunculida are found occasionally and are rare in the Black Sea. For example, Golfingia minuta was observed along the Rumanian coast at $18.5 \%$ salinity (Bacescu and Margineanu, 1959). The lower salinity limit is presumably ca. 18 to $24 \%$ S. The degree of stenohalinity of these organisms increases sharply during reproduction and earlier stages of onthogenesis; hence the appearance of these worms in the Black Sea may be explained by the occasional occurrence of young specimens with highly saline waters (pseudo-populations). However, the sipunculans are evidently incapable of reproduction in the Black Sea.

The most euryhaline forms are the littoral species of the tropical, subtropical and temperate seas. They are subject to seasonal and daily variations in salinity, especially in spring and summer (melting of ice) and rain and drought periods. The inhabitants of the mangroves are a perfect example of tolerance. Phascolosoma esculentum, $P$. onomichianum, $P$. perlucens, populating the upper horizon of estuarine mangrove beaches on the northern coast of the Tonking Bay, are capable of tolerating a $10 \%$ to $30 \%$ reduction in salinity (Gurjanova, 1972). Such abrupt changes may be caused by the summer monsoon blowing for 3 to 4 mo and carrying southern and southwestern hot air and abundant precipitation (up to $491 \mathrm{~mm} \mathrm{~d}^{-1}$ ). The monsoon causes a sharp increase in the water level of rivers and a subsequent significant decrease in the salinity of estuarines. The ability of littoral sipunculans to withstand short-term desalination testifies to their largely eurybiotic nature. Most Sipuncula live under conditions of normal oceanic salinity (lower limit 18 to $26 \%$ S).

Sipunculans are far less sensitive to salinity increases over $35 \%$, thus Phascolopsisi gouldii lives in 19 to $56 \%$ (Adolph, 1936). The Red Sea with its rich and abundant Sipuncula fauna (Murina, 1971) may serve as an example of their natural habitat, characterized by maximal salinities of 40 to $44 \%$.

\section{LITERATURE CITED}

Adolph, E. F. (1936). Differential permeability to water and osmotic exchanges in the marine worm Phascolosoma. J. cell. comp. Physiol. 9: 117-135

Bačescu, M. C., Margineanu, C. (1959). Eléments mediterranées nouveaux dans la fauna de la mer Noire, recontrés dans les eaux de Roumélie (Nord-Ouest-Bosphore). Arch. oceanogr. limnol. 11:63-74

Belyaev, G. M., Birstein, J. A., Bogorov, V. G., Vinogradova, N. G., Vinogradov, M. E., Zenkevitch, L. A. (1959). About the scheme vertical of biological zonality of the ocean (Russ.). Dokl. Akad. Nauk SSSR 129 (3): 658-661 
Chapman, C. (1955). Aspects of the fauna and flora of the Azores. III. Gephyrea. Ann. Mag. Nat. Hist. 8 (12): 351-252

Chin, T. G. (1947). Studies of Fukien Sipunculoidea. Biol. Bull. Fukien Christ. Univ. 3: 97-104

Cutler, E. B. (1973). Sipuncula of the Western North Atlantic. Bull. Am. Mus. nat. Hist. 152 (3): 105-204

Gurjanova, E. F. (1972). The fauna of the Tonking Gulf and conditions of the life in it (Russ.). Issled. Fauny Morei $10(18)$ : $22-146$

Hylleberg, J. (1975). On the ecology of the sipunculan Phascolion strombi (Montagu). In: Rice, M. E., Todorovic, M. (ed.) Proc. Internat. Symp. Biol. Sipuncula and Echiura, Vol. 1. Belgrade, p. 241-250

Kohn, A. (1975). Predation on sipunculans. In: Rice, M. E., Todorovic, M. (ed.) Proc. Internat. Symp. Biol. Sipuncula and Echiura, Vol. 1. Belgrade, p. 313-333

Murina, V. V. (1971). On the composition of species and ecology of sipunculids of the Red Sea (Russ.). In: Sbornik, Benthos shelfa Krasnogo morya. Naukova Dumka, Kiev, p. $76-88$

Murina, G.-V. V. (1977). Marine worms sipunculids of Arctic and boreal seas of Euroasia (Russ.). Opred. Faune SSSR 111. Isdatelstvo Nauka, Leningrad, p. 1-283

Pallas, P. S. (1774). Specilegia Zoologica, Vol. 1 (10). Berolini, p. $1-15$
Rice, M. E. (1976). Sipunculans associated with coral communities. Micronesica 12 (1): 119-132

Rice, M. E., McIntyre, I. C. (1972). A preliminary study of sipunculan burrows in rock thin-section. Caribb. J. Sci. 12 (1-2): $41-44$

Sato, H. (1935). Sipunculoidea and Echiuroidea of the West Caroline Islands. Sci. Rep. Tohoku Univ. 10 (4): 299-329

Sokolova, M. N. (1976). Tropical zonality of the deep-see macrobenthos as an element of the ocean biological structure (Russ.). Okeanologiia 16 (2): 336-342

- Stephen, A. C., Edmonds, S. J. (1972). The Phyla Sipuncula and Echiura. Brit. Mus. (Nat. Hist.) London

Vinogradova, N. G. (1969). The vertical distribution of the deep-sea bottom fauna. In: Kort, V. G. (ed.) The Pacific Ocean, Vol. 7, Biology of the Pacific Ocean, Book 2, The deep-sea bottom fauna, pleuston (Russ.). Nauka, Moscow, p. 129-153

Voss-Foucart, M. F., Barzin, S., Jeuniaux, C., Bussers, J. C. (1978). Etude comparée de la composition chimique des régions souples et dutcies de la cuticula de quarte espèces de sipunculiens. Cah. Biol. mar. 19: 135-145

Williams, J. A., Margolis, S. V. (1974). Sipunculid burrows in coral reefs: evidence for chemical and mechanical excavation. Pacif. Sci. 28 (4): 357-359

This paper was submitted to the editor; it was accepted for printing on December 24, 1983 